\title{
From Brasilia to a Network City: The Reflections of a Russian Sociologist
}

\author{
Oleg Yanitsky \\ Ph.D., Professor, Leading researcher at lab 'RSF-17-45-VP' of the Institute of the Social \\ Philosophy Studies and Mass Communication of Kazan Federal University.
}

\begin{abstract}
I started my professional activity as the urban planner and researcher in the mid1950s after the visit of Oskar Niemeyer to Moscow. The idea of the article is to trace my own perception and views on various models of an 'ideal city' modelling in the context of changing role of large cities in a world social life and the evolution of theories of such cities. Drawing on the study of Russian and foreign literature on urban sociology and planning, on my own theoretical studies and developments and on the participation in three international research projects I came to the following conclusions. First, in the XX and XXI centuries an interest of sociologists and urban planners to the 'ideal city' modelling has not been interrupted. Second, there were two main forms of such modelling: the public discussions and pilot projects making. Third, the most impressive international discussion on the future of cities had been conducted in the Soviet Union in the period of 1929-32s. Fourth, before and after the WWII some of the ideas of that discussion had been realized in the process of restoration of Soviet cities. Fifth, with the beginning of so-called Khrushchev era (1950-mid1960s) an urban planning had experienced two major transformations: a regional planning had been quickly developed and an architectural activity had been divided in two realms: the architecture as such and the 'simple construction.' Sixth, in parallel the search of an 'ideal organization' of everyday life in the form of an ideal neighborhood was continued. Seven, in the end of 1960 s we warned our government and professional community that an era of the Fourth Scientific and Technological revolution (hereafter the STR-4) is coming but that appeal had no response. Eighth, only now our scientific and urban community began to realize that we are entering in the transition period toward the construction of our cities on a network basis.
\end{abstract}

Keywords: architecture, discussions, everyday life, ideal city, networks, regional planning, 'simple construction', society, the STR-4

\section{INTRODUCTION: ON EVOLUTION OF AN IDEAL CITY MODELLING}

Why Brasilia? For me as a young urban sociologist the acquaintance with Brasilia project had been the first step into global urban policy and planning. To begin with, it had been a real geopolitical act aimed at to level an imbalance between the degrees of development of different regions of the country. And it was not a 'paper' but actual project that necessity had been discussed in Brazilian society for tenth of years. Then, the Brasilia project developed by city planner lúcio Costa and then built by the group headed by Oskar Niemeyer had been the result of an open competition. After then, my acquaintance with Brasilia project happened in the years when the Soviet Union was in process of transition from 'classic' style of soviet architecture to its division on the 'architecture as such' and ordinary i.e. mass industrial construction. It has been very important that due to the democracy and kindness of Niemeyer and his colleagues we, the Soviet students were supplied with current literature related to the process of Brasilia construction and discussions about difficulties of it from the first hands. After all, the works of Niemeyer sharply changed my personal perception of possibilities of a concrete as a building material. 
Until the beginning of so-called perestroika, i.e. the transition to market economy in the beginning of the 1990s, the majority of Russian humanitarian intelligentsia comprehends the architecture as a kind of art. Therefore, actually there were three major realms of such 'art': regional planning, 'simple construction' activity and a creation of unique works of art, i.e. buildings designed and built by individual projects. Nowadays, the situation is sharply changed: the 'developers' are everywhere! At the same time urban planning, especially a regional one and construction models of a modern 'ideal city' are practically disappeared from current political and social agenda. This is a main reason why I think necessary to trace the evolution of an ideal city modelling from the very beginning of the XX century till now.

First of all, one should keep in mind that in contrast to Europe the tsarist Russia and then the Soviet Union and the Russian Federation have a vast space for urban developments. At the same time the contrast between relatively densely populated European part of the country and the Asian one that has been very low populated had been critical. Second, this contrast has been resembled in the character of urban planning and habitat. The St. Petersburg was the most European one while Moscow looked like much more 'domestic' one. The cities of the Asian part of the Soviet Union had for a long time been based on local i.e. mid Asian traditions.

Third, the cities of the European part of Russia for a long time have used the Britain principles of urban planning. Two modulo were in favor: the idea of the Garden cities of Tomorrow moved forward by E. Howard (1902) and later, after the end of the WWII a neighborhood principle of urban planning. On the one hand, this principle allowed to a planner to organize any urban space. But on the other hand, it has been insufficient for the structural-functional organization of large regional urban systems with a diversity of its functions.

Fourth, the further the more Russian theoretical thought was moving from the development of the 'ideal cities' models as such to the modelling of regional planning. This trend resembled the planned character of the Soviet economy and social life. The U. Beck's idea that sometimes the 'bads' (Beck, 1999) may bring 'goods' had been confirmed, because at the very beginning of the WWII many plants had been resettled from the European part of the Soviet Union to its eastern part and then remained there gave raise to new industrial centers.

Fifth, at the same time the period of urban discussions ended and the Soviet urban planners had been involved in massive regional planning. Such planning had been rather contradictory because they had to resolve a triple task simultaneously: to develop an industrial potential of a particular region and to coordinate such development with the aims of the State planning institute of the USSR (Gosplan in Russian), on the one hand, and with the needs of other regions, on the other hand. Under such conditions there were no room for urban experiments there were the room to 'paper designing' only.

Sixth, the sharp turn to market economy meant the destruction of already existed or planned industrial and other regions. For about ten years ahead, the life of the cities of Russian Federation (the RF) has been totally dependent on existed gas-oil industry. The accumulation of financial capital has allowed to large cities of the RF quickly develop their suburbs.

Finally, nowadays the RF political leaders moved forward three aims of its development: to struggle with the wastes, to modernize the existing industrial potential, and to begin the shift to the information society (in Russian perechod na tsifry). 


\section{LOOKING BACK TO RUSSIAN URBAN HISTORY}

Such look is necessary because until now the urban potential of the RF is rather diverse: from megalopolises like Moscow and St. Petersburg till small cities and workers' towns built on the principle 'one plant - one workers' town' that are usually called as mono-towns.

The idea that the 'urbanism-des-urbanism' opposition came to Russia from the West is incorrect. Such opposition has been a natural product of a historical development of Russia. Historically large Russian cities were built as the fortresses. But by and large they were gradually become surrounded by various suburbs, the rich and the poor ones. Of course, the British neighborhood exerted an impact but not decisive. Let's look closer on this opposition development.

From the beginning of the XIX century Russian intelligentsia, the architects, designers, writers, journalists as well as politics not only interested in urban matters but all of them played the role of their analytics and critics. For example, the outstanding Russian writer A. Nekrasow edited a collection of essays titled 'A Physiology of St. Petersburg's city', A. Krestowski wrote a novel St. Petersburg slums', and the journalist Vl. Ghilarowsky worked like the Chicago's muckrakers in Moscow slums. On the other hand, there were a group of the architects, historians and journalists who designed and analyzed 'paper projects' of future cities. Our great writer Leo Tolstoy highly estimated works of $\mathrm{Ch}$. Dickens for their empirical evidences related to the London's life of the XIX century.

It's indicative that two outstanding Russian poets, Alexander Pushkin and Mikhail Lermontov, gave the opposite characteristic to the image of St. Petersburg. The former was positive whereas the latter was highly negative. It's important because in their times this capital city created by the Peter the Great has been considered as a model for other Russian large cities. The tradition to use European urban planning had been continued by the empress Katerina the Second. But the history has judged differently and the master plans of the majority of Russian cities usually combined the regular and evolutionary approaches.

One should keep in mind that all said above is related to the period of maturing of Russian capitalism of XIX and the beginning of the XX centuries. Did October revolution of the 1917 and the following critical events like the Civil war of the 1918-22s in Russia roughly changed this trend? Didn't but why?

Town planning, designing and an ideology of urbanism has its own historical-cultural inertia. It doesn't mean that such inertia always took over but as one can see from Russian urban history the regular and evolutionary approaches permanently compete with each other. This competition is highly depends of a particular period of the history.

In the run of XX and the beginning of XXI centuries Russia has passed through eight critical periods, namely: the first Russian revolution of the 1905-07s, the WWI (1914-17), the second Russian revolution of the 1917, already abovementioned civil war, forced industrialization of the 1920-40s, the WWII (1941-45) and restoration period burdened by severe drought in the 1946, and finally the 'bourgeois' revolution and beginning the transition to market economy in the 1990s. The each of them has been accompanied by critical events, human, territorial and material losses and total restructuration of institutional structure of Russian society within each of the above critical periods. But all attempts to radically change an urban politics and town planning sooner or later failed. 


\section{SOME THEORETICAL PREREQUISITES}

First, there are some underpinnings for any science-urban politics relationships. In April 2017, that in the midst of Russian second revolution world-known Russian scientist and scholar, coauthor of the biosphere concept Vl. Vernadsky had made a set of principled points related to the further development of Russian state and its urban politics. They are as follows: (1) a researcher has to comprehend politically and socially a giant scale of Russian territory; (2) Russia is the Euro-Asian state and the further the more it will become the Asian one; (3) Russian science is a state social institution; (4) that institution is united and therefore inseparable; (5) a network of the state research institutes is a basement of national wellbeing and safety; (6) we must know much more about local life and local needs; and (7) a scientific work is a free creative process and is not subjected to state regulation (Vernadsky, 1995: 241249).

Second, just after two revolutions, the WWI and civil war a creative potential of Russian intelligentsia had been seriously weakened. It had been the hunger, cold and absolute zero in financial supply. There was only one way out: to mobilize his/her creative potential and to analyze the state of matters and to model Russian future in the form of the 'paper projects.'

Third, paradoxically but two or even three first decades of XX century had been the most successful for production of new ideas in urban planning and new forms of social life and some of them had been practically tested. Of course, it had been the individual ideas and projects but they showed that current social disturbances may bring very fruitful results in the future.

Fourth, social constructivism had been dominated. We are now speaking on a kind of 'dramatizing sociology' and the role of mass-media in this process. In those times the urbanists tried to organize directly new social life and to construct for it new architectural forms and master plans in accordance with the models of desired future.

Fifth, recently for the reason of a necessity of the rapid transition of Russia to the STR-4 (i.e. the transition toward social life based on information-communication processes) the sciencepolitics relationships and accordingly the very idea of an 'ideal city' modelling should be seriously transformed.

\section{THE FIRST DECADE AFTER THE OCTOBER REVOLUTION (1918-29)}

The distinguishing feature of this period is a division of Russian intelligentsia in two parts: those who emigrated and attempted to comprehend the revolution and its social consequences distantly and those who considered the above critical event as a challenge to their creative potentials. The architects and city planners belonged to the second part.

Since every revolution generate a social chaos, the old social institutions failed and the new ones were only in the process of construction that period was marked by a raise of civic initiatives in all spheres of social life. This thesis had been confirmed by such raise in all eight critical periods of Russian history. On the other hand, the already existed forms of urban life, for example, the suburban summer settlements (dachas) peculiar to large pre-revolutionary large cities have been revitalized.

As to urban planning, there were two mainstreams. The former was marked by the 'paper design and urban planning' and the latter by some attempts to revitalize the 'garden-city of tomorrow' ides in new social and political conditions. I'd like to mention that the ideas of a 'linear city' and a 'horizontal apartment house' have been moved forth by Russian artist and architect El. Lisitsky. 


\section{THE 1929-30S: THE DISCUSSION ON A SOCIALIST CITY}

It had been a unique discussion for many reasons. First, the representatives of a very socially and politically diversified Russian society took part in it. It had been the painters, architects and city planners, the scientists and scholars, the young and the old, etc. Nadezhda Krupstaya, the widow of Vladimir Lenin, and the head of the Commissariat of Peoples' Enlightenment A. Lunacharsky and many other Russian state officials, politicians and engineers took part as well. Thus, this discussion maybe considered both as the all-Russian and international one. Le Corbusier, E. Mai and some other European urban theorists and urban planners took part in it (Kopp, 1967; Meerovich, 2016).

Second, it had been the most democratic discussion in the Russian and Soviet history. The left and the right had a right to say. The future of Russian cities had been analyzed and projected in the context of the very beginning of massive industrialization and urbanization of the country. From the very beginning the discussion had acquired a character of the battle between the urbanists and des-urbanists. Actually the urbanists considered new socialist cities as an element of the state government politics of industrialization and urbanization. The desurbanists were the adherents of a more private life and therefore of a more spatially-dispersed human settlements.

Third, the foreign participants of the above discussion divided in two wings as well. Le Corbusier presented the left radical one. He actually offered to destroy totally the existed Moscow (except some historical and cultural monuments) and on its territory to construct a giant garden-city built by multistory apartment houses. The more realistic urban designs were offered by those European architects who later took part in the master plans making of new industrial cities.

Fourth, the leaders of the Communist party of the Soviet Union had considered this discussion as a threat to their monopoly for political domination from the re-emerging civil society and in the run of the early 1930s had made extra-efforts to subject this variety of civil initiatives and the NGOs to the state-controlled unions of the writers, artists, architects, etc.

Fifth and the most important is that the discussion on a Socialist City had emerged in the process of compiling of the First Five-Year plan of the Soviet Union. Actually in the 1930s and later on the socialist cities planning and their living facilities have been considered by the Communist party and state leaders as an instrument of control on the productivity of labor of the workers recruited from the yesterday peasants.

\section{FROM THE 1930 TO THE 1941}

It has been the times of intensive industrialization and urbanization accompanied quite naturally by mass resettlement of the peasants to large cities and transformation them into industrial centers. New industrial cities like Magnitogorsk had been built (Kotkin, 1991) while the old cities like Nizhnyi Novgorod were transformed into the largest center of motor plant. New industries required thousands working hands hence the construction of the schools of secondary technical education was intensified. It's interesting that the city of Stalingrad had been planned and built as a 'linear city.'

The Moscow city as the capital of the Soviet Union is considered and built as an 'ideal socialist city.' The most ambitious projects like the project of the 'Palace of the Soviets' had been considered as an embodiment of a socialist future. Stylistically, it had been the period of socalled 'Stalin-empire' shaping. The Moscow's tube (underground) is the best example of it because every station presented a work of art propagated labor and wellbeing. All in all, in the 
beginning of the 1940s the Soviet Union had turned into highly-centralized political and social state. The process of rehabilitation of the European part of the country is beyond the scope of this article. It should be mentioned only that a creative potential of the Soviet architects and urban planners had been mobilized.

\section{AFTER THE WWII END TO A MASS INDUSTRIALIZATION OF THE HOUSING CONSTRUCTION}

The Stalin's death in March 1953 meant the turn to more democratized social life but it didn't mean the end of the abovementioned trends. The further the more the Soviet cities and towns continued to be divided in three parts: political and administrative center, the islands of historically constructed buildings and a number of small settlements belonged to a particular plants or industrial complexes. When I began to work as the practical urban sociologists I'd been astonished by these neighboring but separately planned and supplied zones.

In the 1954, the new Communist party leader Nikita Khrushchev voluntary divided a total constructing activity of the Soviet architects and urban planners in two realms, the architecture as such and the 'simple construction.' The latter meant to put on stream the housing construction under the slogan 'To every family - their own apartment.' Besides, Khrushchev attempted to decentralize spatial planning giving more rights to regional authorities but failed.

In the 1960s there were several attempts to design an 'ideal region model' (Gutnov and Lezhava, 1966) but as one can see now it had been one more 'paper design' and no more because such projects had never been considered as an inseparable part of particular industrial, political, social and natural environment.

One public event has to be mentioned especially. I mean the VI Festival of the Youth and Students in August 1957 held in Moscow. It had been the festival of all-embracing democracy, mutual trust and understanding after which the 'Iron Screen' between the Soviet Union and the rest world was impossible.

\section{ARCHITECTURE AND URBAN PLANNING AFTER THE 'PERESTROIKA' (1991 AND ONWARDS)}

The radical changes in these two spheres after 1991 and onwards deserve special attention. Therefore, here I'd count the major changes that exerted the most substantial impact on the architecture and urban planning after the Soviet Union decay.

First, the 1990s meant a decisive break with the socialist past and the turn to building a market economy. It had been the hard times to a majority of population of the Russian Federation (the RF) and the shaping of the islands of a 'wild market.' the architect and urban planner as the creators of urban fabric had been quickly replaced by the developers as the agents of the state or private capital.

Second, in the above times a majority of existing cites were in decay except those that had been tightly connected with gas-oil and some other resource export-oriented industries. It meant the decay of the cities and towns that worked on local and regional markets only. It means a growing gap between the rich and the poor. The former were disinterested in urban matters because they lived in the suburbs or abroad while the poor remained immobile.

Third, Moscow and some other large cities have become the centers of gravity of labor force both of the residents from the small settlements and from the post-Soviet countries. Therefore 
the imbalance between large and small cities and between the European and the Eastern parts of the Russian Federation continued to grow. Only two years ago an interdisciplinary group of Russian and English specialist began to work on the qualitative model of the Russian green city (Ermolaeva, 2017) but this project is still in process.

Fourth, Russia has quickly turned into consumer society that meant a rapid growth of amount of various wastes. At the same time the under-class recruited from jobless and homeless people has emerged. Z. Bauman has named these people as the wasted ones (Bauman, 2004). Besides, an amount of commuters between the large cities and province grew rapidly.

Eighth, very quickly the urban planning as a social institution has been replaced by ad hoc privatization of land or marine areas potentially capable to bring profit. The flows of foreign migrants from the Mid Asia and Ukraine and those who left Russia forever coupled with a redistribution of urban residents within Russian Federation disorganize human settlements much more than earlier. To my mind, in a mobile market economy the very notion of a city is substantially changing.

\section{Towards a network city concept}

I began to study the impact of information-communication processes on urban structures from the early 1970s onwards (Yanitsky, 1970, 1972). But neither sociological nor urban Russian community didn't respond to this global challenge. Almost half-a-century had to pass before our scientific community began to analyze this phenomenon of primary importance. As the urban sociologists and city planners showed no interest to it, the technocrats took over the leading positions in the methods and processes of comprehension of that new phenomenon.

There is no room to analyze the roots of such methodological shift but the technocrats' starting point was the STR-4 and its social and other consequences. I think that this position is wrong because of the information-communication processes are all-embracing and all-penetrating. As M. Castells pointed out many times, the key problem is a qualitatively new type of structuralfunctional organization of modern world. We are dealing not with an impact of information technologies on a particular social object but with a new type of global community in the network of which various cities are included (Castells, 1996).

\section{Visible effects}

These effects are the result of the process of transferring a set of manual or intellectual operations initially implemented by man himself to the 'smart machines.' To protect himself from unemployment and misery the man is obliged either to get permanently new knowledges and crafts or/and to be very mobile that is to be capable to change a habitual place of life, to be ready to say goodbye to his/her relatives and friends, and to adapt quickly to new climatic conditions and social milieu, etc. that is to become mobile and uprooted. It also means a submission to numerous new rules, codes, and protocols that is, in the final analysis, to be maximally externalized because a social potential acquired in one place will be unnecessary in another one. An individual is becoming a functional element of the global informational machine. As a result, his/her behavior reminds me the Brownian movement in which the individual becomes alienated.

\section{Invisible effects}

A functioning of an informational 'machine' is usually unseen, be it transmission of knowledge as such, codes and rules, the recommendations, instructions and commands or the financial flows. Only the operators of the smart machines know where and how a particular information or personal data are stored and how they are protected. Invisible functioning of smart machines system is another form of man's alienation from the structures and functions of 
global world. And there is no way out from such state because if the man wants to be a member of a 'smart society' he must trust him without any guarantees. It means that the man has no real choice - he is obliged to choose his/her decisions from already existed set of variants. And only the little minority, called the 'creators' are allowed to construct new decisions and set of information. Thus, the informational society constructs its own social hierarchy. But the powerful global market is capable to destroy any innovative corporation if it's not fit to quickly changing conditions. It's a dialectical process when such destructions are a clearly visible effect of invisible processes and functions.

\section{Global in local}

The notion of 'glocalizaion' had been introduced by R. Robertson in the frames of the 'Western project of modernity' (Robertson, 1994). Under the conditions of the STR-4 it's rather conditional to separate local from global. And their interdependence is one more distinguishing feature of an 'informational model' of our world. It is the STR-4 has made the global and local notions very conditional. A 'weakness is the strength' is the well-known maxima of our times. The 'local as global risk' principle is also relates to natural world because all living species are evolutionary adapted to a particular natural environment and climatic conditions. And if such conditions are sharply changed or a particular virus occurred in favorable conditions it meant the threat of epidemics with unknown consequences. The more the man is travelling across the globe the higher a probability of transferring such epidemics from one place to another one. It's one of the reasons why the reach builds the isolated islands of their wellbeing within a city's fabric. In such mobile and uncertain local-global context the 'sustainable city' notion is finally lost its sense. In such context a sustainable state of a particular city is only a moment in its permanent multi-sided and multi-speed transformations.

\section{Hybris wars as an integrated result of the STR-4}

To my mind, the modern world is already in the state of numerous hybrid wars since the information production, dissemination and competition has become all-embracing and allpenetrating. Besides, the wars in this era are impossible without mutual understanding between natural, social and technical sciences. Thus, the interdisciplinary approach is a necessary precondition for a win in any hybrid war.

Then, if we are dealing with the 'inversion of the space' phenomenon the tempo-rhythms of local-global processes are becoming one of the arms in such wars. As Russian theorist of modern wars argued (Sivkow, 2018) the optimal combination of quick information attacks and long-term information and economic pressure are one of the most efficient strategies of such wars. The author underscored that successful modern (hybrid) war is a complex of the measures of various scale and different in their duration. He stated that operations of the geopolitical scale are the highest form of modern wars. The other authors underlined the growing role of the mems as the deep structures of human consciousness that are often used in informational attacks on possible adversaries. The existing mems are exerting impact on decision-making processes. A. Bartosh called the mems as the accelerators of hybrid wars (Bartosh, 2018). To my sorrow, the sociologists escape to study modern wars as an inseparable factor of the STR-4 evolution.

\section{Challenges to various sciences}

It's now obvious that the STR-4 and its numerous consequences are the interdisciplinary phenomena, in which natural, social and technical structures and processes are tightly interconnected. The biology and other natural sciences widely use the term of metabolism i.e. the processes of interactions and mutual transformation of the substances and structures of various origin. 
For me it's a rather surprisingly that many social sciences and humanities are still not widely used the interdisciplinary approach. Today, the very existence of such disciplines as the history and archeology as well as the medicine and many others are impossible without a various forms of metabolic analysis. Let's take the only one example. The local lore studies are absolutely impossible without the study of metabolic processes between a lot of structures and processes of different origin (Lichachev, 1982). Finally, our daily activity is an endless chain of qualitatively different actions. In spite of construction various 'smart machines' an experienced person is usually much higher values this craft than an 'one dimensional man.' Therefore, we are needed not in transdisciplinary studies (this notion is still has never been carefully defined) but in the interdisciplinary ones.

\section{Shaping global environment}

Growing an overall uncertainty is produced by: the overpopulation of the planet; by growing resourced deficit and by the struggle for access to them, sharpening struggle between global superpowers, on the one side, and the national and transnational corporation, on the other for sources of resources and geopolitical domination; by inequality in transition towards the STR4; by the natural and man-made catastrophes and the speed of adaptation to their consequences; by the struggle of the minorities for their survival, etc.

In the information epoch an issue of the relationships between an actual natural processes (including the biosphere turnover) and the processes and structures constructed and governed by a man is becoming the central for humanity survival. On the one hand, undoubtedly humanity will initiate new technological revolutions (biotechnical, genetic, etc.). On the other hand, there are limits to growth of world population and the consumer ideology. This double growth can't be overcome by technological inventions only. It means that global processes require global economic and political measures and first of all a sharp reduction of production of wastes. The reverse side of the same coin is a necessity of the restriction of consumer ideology and politics. In turn, it means the control over the mass-media activity, etc. Within the above trends and socio-political measures a coming network-city will look like the hubs of transition, exchange and metabolic processes.

\section{RESULT: A MAN IS AN APPENDAGE OF A 'SMART MACHINE'?}

It's the most difficult question because in the information society the man is under pressure from many sides. To be not an appendage of the above machine every man must have its own private space but this space is constantly violated by numerous information flows. On the other hand, if the man wants to be an agent (an actor) he must be maximally included in the world network fabric. And this equilibrium is permanently violated from both sides.

Then, this topic has many other aspects, political, social, cultural, and environmental. The political one has, from my viewpoint, two main dimensions. The former is a growing gap between the existing political institutions and a permanently changing political 'climate.' The decision has been found in an endless chain of talks, permanent agreements and other temporary instruments. The latter is a speeding up of production of temporary directives, instructions, codes and protocols.

The social dimension is in growing destruction of existed social forms (societies, communities, neighborhoods, small groups, etc.) and replacing them by virtual communities and human ties. In a modern very mobile world it's rather difficult to maintain stable territorial, professional and human communities. Besides, in our corporative world there is a tendency to shift the responsibilities from the top officials and managers onto the shoulders of the rank-and-file workers. 
The cultural issue is generated by the same high mobility factor. A permanent mobility makes the man uprooted from his/her habitual living and cultural milieu, and therefore the question emerges: who will care for his/her Small Motherland? Who will maintain a cultural diversity of numerous traditional and aboriginal clans and communities?

But from my viewpoint, the environmental question is the most acute. A man (as humanity as a whole) is forced to restrict the use of the resources and other consumer appetites. In such local-global context, its socially-constructed and machine-governed i.e. the sociobiotechnical environment will grow. If the man is both a constructor and servant of that environment his/her dependence of it will inevitably grow. The above question is aggravated be the fact that dynamics of the sociobiotechnical environment is not well studied.

The same conflictual situations one could see on all other levels including an individual one. In other words, we see the dialectical interdependence between global and local: the more man interferes into a natural environment and its ecosystems the more he/she is dependent on them. At last, all natural and man-made systems including the biosphere have their carrying capacity, and if it is surmounted the destructive processes begin accompanied with the emanation of giant masse of energy of decay, be it natural or man-made disasters or epidemics, mass migration and other unpredictable processes. Therefore, a man as the appendage of a 'smart machine' is only a particular case.

\section{CONCLUSION}

The 'Brasilia construction process' played an important role in the shaping of my comprehension of an 'ideal city' modelling and its realization in situ. For the first time I understood how difficult and contradictory may be the 'transition' from the project of a master plan to its realization.

I also understand that even in those times a national and global reality had been changing much faster than its comprehension by the scientists and practical realization. Looking back, I'm forced to recognize that U. Beck (1992) was right: we are now living in and dealing with the side-effects of national and global processes and events. But at the same time I realized that the making of 'ideal cities' models is rather important both from the urban planning and symbolic viewpoints of future social life.

Russia which has passed through eight critical periods during last 100 years was not capable to coordinate (to synchronize) its urban politics, especially regional one with this chain of radical national and global transformations. Taking into account a growing tension between Russia and the Anglo-Saxon world and the necessity to mobilize our national resources for transition toward the STR-4 this gap will be widening. I consider the STR-4 as a multisided process of global community transition toward information-communication network-based mode of production and social reproduction.

A transition to the STR-4 generates a qualitative changes in a global community-particular city relationships. Actually, a city as a main form of concentration of industrial and social forces and therefore the growth of the strength of given nation-state is gradually reducing. Step by step modern cities are transformed into a transaction area of global and national flows of information and a space of various metabolic processes. From this viewpoint, an efficiency of such transaction areas should be measured in the terms of a speed of access to a global information clouds and flows, safety, easy access to information networks and standardized living environment. 
The transformations generated by the STR-4 are as follows: (1) information-communication mode of production and social reproduction is becoming a leading force in the life of global community; (2) a global struggle for all kinds of resources and geopolitical domination will strengthening; (3) the cities' life will become more subjected to global processes; (4) a material structure of the cities may remain the same while the transformation of their information functions will permanently accelerate; (5) an overall uncertainty of global network cities will grow; (6) a population of these cities will divide in two parts: a minority of the 'creators' and a majority of the 'users' of production of global network 'machine'; and (7) in the run of the STR4 process the strengthening of the integrative forces of informational processes the very notion of a living environment will substantially change.

All said above is only my hypotheses based on current well-seen and overt trends because the further the more the globalization processes will have nonlinear character burdened with qualitative changes and unintended consequences. Already recently we see the opposite trends, namely towards a restoration of local communities and neighborhoods and the search for friendly interpersonal relations.

Funding: the research was supported by Russian Fundamental Research Fund under the grant 'Russian megacities in the context of new social and environmental challenges: building complex interdisciplinary model of an assessment of "green' cities in Russia"', project No 1778-20106.

\section{References}

Bartosh A. 2018. The Accelerators of Hybrid Wars: Colored Revolutions are initiated by 'mental virus.' VoennoPromyshlennyi Kurrier. No 46 (757): 04 (in Russ.).

Bauman Z. 2004. Wasted Lives. Modernity and its Outcasts. Cambridge, UK: Polity Press.

Beck U. 1992. Risk Society. Toward a New Modernity. London: SAGE.

Castells M. 1996. The Information Age: Economy, Society and Culture. Oxford, UK: Blackwell.

Gutnov A. and Lezhava I. 1966. New element of Town-Planning: Towards a new City. Moscow: Stroyizdat.

Ermolaeva P. 2017. Russian Megacities in the Context of New Social and Environmental Challenges: building Complex Interdisciplinary Model of an Assessment of 'Green Cities' and Strategies of their Development in Russia, in: Sustainability Transitions Research Network. Newsletter 26, December 2017, p. 5.

Lichachev D. 1982. An Ecology of the Culture. Knowledge is the power. № 6, C. 22-24. (in Russ.).

Meerovich M. 2016. A Soviet City in the Discussion of the 1929-31s. Ural'sky Historical Vestnik, N 3 (52): 101-111. (in Russ.).

Kopp A. 1967. Ville et revolution. Architecture et urbanisme sovietique des annees vingt. N.Y.: Alfred A. Kopp.

Kotkin St. 1991. Steeltown, USSR: Soviet Society in Gorbachev Era. California: Univ. of California Press.

Robertson R. 1994. Globalization. Social Theory and Global Culture. Thousand Oaks, Calif.: SAGE.

Sivkov K. 2018. A Power of Slow Down Impact. Voenno-Promyshlennyi Kurrier. No 46 (757): 04 (in Russ.).

Vernadsky Vl. 1995. The Tasks of Science in Connection with State Politics in Russia, pp. 241-249, in: Vernadsky Vl. Publicist articles/ed. by V. Volkov. Moscow: Nauka (in Russ.).

Yanitsky 0. 1970. Socio-informational Aspects of Urbanization. Paper presented at the VII World Sociological Congress. Varna, Bulgaria.

Yanitsky 0.1972. Social-informational processes in a society and urbanization, in: Yanitsky 0., ed. Urbanization, scientific and technological revolution and the working class. Moscow: Nauka, pp. 76-96. 